\title{
Characteristics of Biosurfactant Produced by Pseudomonas sp. G314
}

\author{
So Hee Shim ${ }^{1}$ and Kyeong Ryang Park²* \\ ${ }^{1}$ Department of Microbiology, College of Medicine, Korea University, Seoul 136-705, Korea \\ ${ }^{2}$ Department of Biotechnology, Hannam University, Dajeon 305-811, Korea
}

Received December 30, 2011 /Revised February 13, 2012 /Accepted February 14, 2012

\begin{abstract}
The purpose of this paper is to analyze the characteristics and chemical components of biosurfactant produced by Pseudomonas sp. G314. Pseudomonas sp. G314 was isolated from soil samples which were contaminated with oil in Daejon area. As such, it produced quality biosurfactant [23]. One type of biosurfactant was kept in a refrigerator, whereas another type of biosurfactant was kept in room temperature. The surface tension activities were then compared. As a result, the biosurfactant from Pseudomonas sp. G314 that was kept at room temperature was stable for 10 days, showing 26.2 dyne/cm of surface tension activity. This result was found to be similar to that of the refrigerator storage. The surface tension of batch culture was $25 \mathrm{dyne} / \mathrm{cm}$, but the culture in the 51 fermentor was $27 \mathrm{dyne} / \mathrm{cm}$. Therefore, it can be suggested that the large-scale culture is feasible via the fermentor. Biosurfactant from Pseudomonas sp. G314 was estimated to be a kind of glycolipid because it dissolved in acetone and methanol much better than in benzene and toluene [23]. A spot was detected through the elution of silica gel column and the spread of TLC, and the Rf value was 0.58. This spot has a positive reaction with Bail's reagent and rhodamine 6G. Hence, we can conclude that biosurfactant from Pseudomons sp. G314 was a glycolipid containing carbohydrate and lipid.
\end{abstract}

Key words : Biosurfactant, glycolipid, Pseudomonas sp. G314, surface tension

\section{서 론}

계면활성제(surfactant)는 한 분자 내에 친수성기와 소수성기 를 함께 갖는 양친매성 분자로 표면이나 계면의 성질을 변화시 켜 표면장력을 감소시키기 때문에 건설, 기계, 전기, 전자, 제지, 섬유 등 각종 산업에 폭 넓게 이용되는 물질로, 성분에 따라 화학 적으로 합성되는 화학합성 계면활성제(chemical surfactant)와 미생물이 생산하는 생물 계면활성제(biosurfactant)로 구분할 수 있다.

일반적으로 화학합성 계면활성제는 상대적으로 단가가 저 렴하여 많이 사용되지만 이들은 난분해성 물질로 생분해도가 매우 낮아 독성을 나타내고, 거품을 형성하여 물 속 생태계를 위협하는 등 많은 환경문제를 야기 시킨다. 반면, 효모, 곰팡 이, 박테리아 등 다양한 미생물이 세포 외 또는 세포 내에 생산 하는 생물 계면활성제 $[15,17]$ 는 화학합성 계면활성제에 비해 무독성으로 생분해가 용이한 친 환경적 물질일 뿐 아니라, 다 양한 온도와 $\mathrm{pH}$ 에서도 계면활성제의 물리 화학적 성상을 안 정하게 유지하므로 그 사용가치가 매우 높아 최근에 관심을 갖는 물질이다. 따라서 계면활성제가 갖는 이런 독특한 성질 때문에 생물 계면활성제는 식품, 제약, 화장품, 농산물 가공업, 생물정화(bioremediation) 등에 다양하게 활용되고 있고 $[2,12,20]$, 최근에는 일부 생물 계면활성제가 병을 치료하는 효

*Corresponding author

Tel : +82-42-629-8770, Fax : +82-42-629-8769

E-mail : krpark@hnu.kr
과를 갖고 있어 의약품으로도 활용할 수 있고[21,24], 또 병원 성 미생물이 인체에 부착하지 못하는 하는 효과[10]도 있는 것으로 확인되는 등 많은 연구가 진행되고 있다.

현재까지의 연구에 의하면 다양한 생물 계면활성제 중 Pseudomonas sp.가 생산하는 rhamnolipid 계열의 계면활성제 [11]와, viscosin [16], putisolvan [14], 그리고 Bacillus subtillis 가 생산하는 surfactin [1] 같은 lipopeptide 계열, Acinetobacter calcoaceticus가 생산하는 emulsan [22] 등이 잘 알려져 있다.

본 연구는 이처럼 친환경적이며 여러 분야에 다양한 용도로 사용될 수 있는 생물 계면활성제를 산업적으로 활용하기 위한 연구의 일환으로, 자연계에서 분리하여 생물 계면활성제 생성 이 우수한 것으로 확인된 Pseudomonas sp. G314가 생산하는 계면활성제를 정제하고 이에 대한 특성을 파악하여 추후 이를 상업적으로 활용하고자 하였다.

\section{재료 및 방법}

\section{사용 균주 및 배지}

Shim과 Park [23]의 논문에서 보고된 대전일원의 유류오염 지역의 토양에서 분리한 생물 계면활성제 생성이 우수한 Pseudomanas sp. G314균주를 균주 배양에 가장 많이 이용되는 Luria-Bertani (LB)배지(tryptone $10 \mathrm{~g} / \mathrm{l}$, yeast extract $5 \mathrm{~g} / \mathrm{l}$, sodium chloride $5 \mathrm{~g} / \mathrm{l}, \mathrm{pH}$ 7.0)에서 배양하며 본 실험에 사용 하였다. 


\section{표면장력 측정}

$\mathrm{LB}$ 영양배지에서 $\mathrm{OD}_{600}=1.0$ 까지 전 배양한 균주 $5 \mathrm{ml}$ 을 500 $\mathrm{ml} \mathrm{LB}$ 배지에 접종한 후 $30^{\circ} \mathrm{C}$ 에서 $200 \mathrm{rpm}$ 으로 진탕 배양하 며 배양시간에 따라 시료를 일정량 채취하였다. 채취한 시료 는 원심분리기(supra22K, Hanil Science, Korea)로 원심분리 $(13,000 \times g, 10$ 분 $)$ 하여 균체를 제거한 후, Surface Tensiometer (CBVP-A3, FACE, Japan)를 사용하여 plate 방법[3]으로 $25^{\circ} \mathrm{C}$ 에서 3회 반복하여 표면장력을 측정하였다.

\section{자동 발효기를 이용한 계면활성제 생산}

선별 균주가 생산하는 생물학적 계면활성제를 추후 대량으 로 확보할 수 있는지를 확인하기 위한 예비실험으로 51 의 발 효기(KF-5L, 한국발효기, Korea)에 21 의 배지를 첨가하여 배 양하였다. 이때 배지는 $\mathrm{LB}$ broth를 이용하였으며 $30^{\circ} \mathrm{C}, 400$ $\mathrm{rpm}, 1: 1 \mathrm{vvm}(2 \mathrm{NV} / \mathrm{min})$ 의 조건에서 실험하였다.

\section{생물 계면활성제 정제}

Psudomonas sp. G314의 전 배양 용액을 11 영양배지에 접종하여 $30^{\circ} \mathrm{C}$ 에서 진탕 배양한 후 Fig. 1 에 표기한 순서에 따라 정제하였다. 배양 용액은 원심분리 $(13,000 \times g, 10$ 분 $)$ 를
통하여 균체를 제거한 상등액에 $1 \mathrm{~N} \mathrm{HCl}$ 용액을 서서히 가 하면서 $\mathrm{pH} 2.0$ 이 되도록 조정하였다. $\mathrm{pH}$ 를 조정한 상등액 을 동량의 chloroform:methanol (2:1)을 가하여 저어주면서 $4{ }^{\circ} \mathrm{C}$ 에서 하룻밤 방치하여 추출하였다. 그 후 분액깔대기를 통하여 유기 용매층 만을 회수하여 Rotary Vacuum Evaporator (N-N series, Eyela, Japan)로 농축하고, 이를 0.2 $\mathrm{M}$ phosphate buffer (pH 7.0)에 용해시킨 후 동결건조기 (Freezone 4.5, Labconco, USA)를 이용하여 분말 상태로 만 들었다. 이와 같이 부분 정제된 생물 계면활성제는 냉장 보 관하며 다음 실험에 사용하였다.

\section{생물 계면활성제의 성분조사}

생물 계면활성제의 성분을 조사하기 위해, 용매추출을 통하 여 얻어진 부분 정제된 시료를 소량의 methylene chloride:methanol:acetic acid (7:1:1\% (v/v))의 혼합용매에 용해시 킨 후 동일 용매로 평형화 된 silica gel 60 (Merck Co., mesh 230-400) column $(2.5 \mathrm{~cm} \times 30 \mathrm{~cm})$ 에 흡착시켜 용출시켰다. 그리고 용출된 분획 중 표면장력 활성이 가장 우수한 분획을 silica gel G F $F_{254}$ plate (Merck, Germany, $20 \mathrm{~cm} \times 20 \mathrm{~cm}$ )를 이용하여 thin layer chromatography (TLC) 전개 실험을 실시

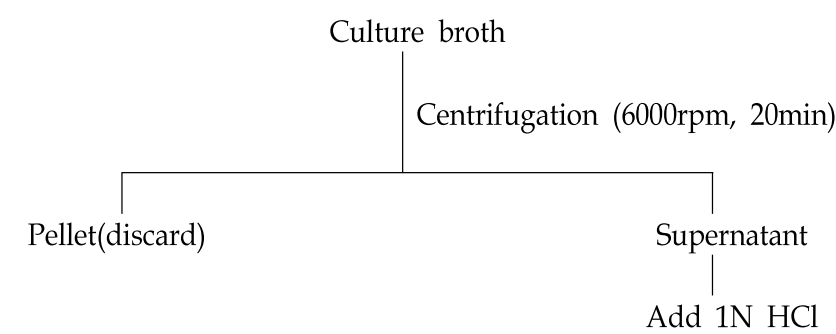

adjustment to $\mathrm{pH} 2.0$

Equal vol. $\mathrm{CHCl}_{3}: \mathrm{MeOH}(2: 1)$

extract

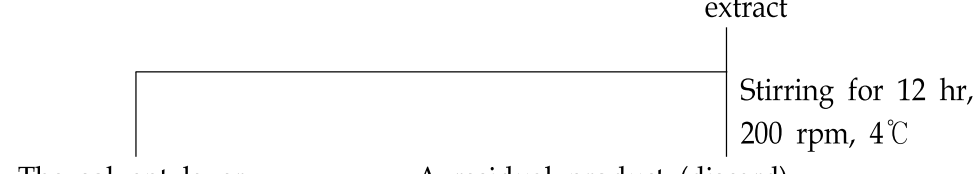

The solvent layer A residual product (discard)

Evaporate the solvent at $50^{\circ} \mathrm{C}$

Extraction of crude biosurfactant

silica gel column chromatography

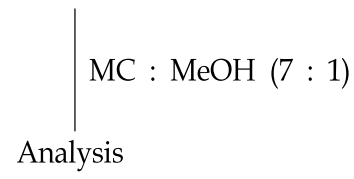

Fig. 1. The steps of isolation and purification of biosurfactant from culture broth. 
하였다. 이때 전개 용매로는 methylene chloride:methanol:acetic acid (7:1:1\%), methylene chloride:methanol:ammonia water (100:10:1), chloroform:methanol: $\mathrm{H}_{2} \mathrm{O}$ (65:25:4), chloroform:methanol:acetic acid (65:25:4), chloroform:methanol:5 $\mathrm{M} \mathrm{NH}_{4} \mathrm{OH}$ (65:30:5), hexane:isopropyl alcohol:methanol (70:35:15), chloroform:aceton:methanol:acetic acid: $\mathrm{H}_{2} \mathrm{O}$ (7:8:2:2:1) 등 다양한 용매 조합으로 전개를 실시한 후, 분리 상태가 가장 우수하게 나타난 methylene chloride:methanol:acetic acid (7:1:1\% (v/v))의 조건으로 모든 실험 을 실시하였다. 그리고 TLC plate 상에서 전개된 spot은 UV lamp (VL-6, vilber, $\mathrm{EEC)}$ 로 $254 \mathrm{~nm}$ 와 $365 \mathrm{~nm}$ 의 파장으로 확인하였다. 또 TLC상에서 발견된 spot의 생화학 반응은 당의 발색시약으로는 Bial's reagent (orcinol-ferric chloride), 아미 노산의 발색시약으로 ninhydrin, 단백질 발색시약으로 pyridine, 그리고 지질의 발색시약으로 rhodamin $6 \mathrm{G}$ 를 이용하여 분석하였다.

\section{결과 및 고찰}

\section{Psudomonas sp. G314 균주의 특성}

Shim과 Park [23]은 유류로 오염된 토양에서 생물 계면활성 제 생산능력이 우수한 균주인 Psudomonas sp. G314를 분리하 고 이 균주의 특성을 조사하였다. Shim과 Park [23]이 분리한 Pseudomonas sp. G314가 생성하는 생물 계면활성제의 표면장 력은 Pseudomonas fluorescens [6]와 Bacillus licheniformis [13], Bacillus subtilis [18]가 생산하는 27 dyne/cm, Pseudomonas aeruginosa [11]가 생산하는 25-30 dyne/cm, Ustilago maydis[5] 와 Corynebacterium lepus [4]이 생산하는 $30 \mathrm{dyne} / \mathrm{cm}$ 보다 우 수하고, critical micelle concentration (CMC) 값도 $20 \mathrm{mg} / 1$ 를 나타내, 지금까지 연구된 다른 생물 계면활성제에 비해 표면 장력 활성이 매우 우수한 것으로 확인되었다(Table 1). 또 온도 에 대한 안정성, $\mathrm{pH}$ 에 의한 생육 안정성 등 여러 가지 특성도 뛰어나 오염된 토양이나, 담수 그리고 해수에 적용시켜 환경 정화에 사용하기에 적합한 균주 임을 확인되었다. 뿐만 아니 라 추후 본 실험에 사용된 LB배지 대신 계면활성제 생성을
증가할 수 있는 적합한 배지를 개발한다면 더욱 많은 량의 계면활성제를 생성할 수 있을 것으로 생각된다.

\section{생물 계면활성제의 유화활성}

Pseudomanas sp. G314의 증식과 생물 계면활성제 생성과의 상관관계를 알아본 결과, 대수 증식기에 이르는 3시간 이후부 터 표면장력이 급격히 감소하여 7시간 후에 배지의 표면장력 이 최대 $25 \mathrm{dyne} / \mathrm{cm}$ 까지 저하되고 저하된 표면장력은 30시간 이상 장기간 유지됨이 확인 되었다[23]. 그리고 표면장력이 최 대일 때 균체를 제거한 배양액의 계면활성제 활성 유지 정도 를 확인하기 위해 일정량씩 분주해, 하나는 상온보관하고 다 른 하나는 $4^{\circ} \mathrm{C}$ 에서 보관하면서 일정 시간 간격으로 계면활성 제의 표면장력 측정한 결과(Fig. 2), 상온과 냉장 보관한 시료 모두 3일 동안 $25 \mathrm{dyne} / \mathrm{cm}$ 를 유지하였고, 4 일 이후에도 비슷 한 표면장력을 유지하여 10 일 경과 후 상온 보관은 $26.2 \pm 0.2$ dyne $/ \mathrm{cm}$, 냉장 보관은 $25.8 \mathrm{dyne} / \mathrm{cm}$ 의 표면장력을 나타내 상온보관과 냉장보관의 차이가 거의 없는 것으로 확인되었다. 그러나 측정 11 일 이후 상온 보관은 $26.5 \pm 0.1 \mathrm{dyne} / \mathrm{cm}, 12$ 일 이후 $27 \mathrm{dyne} / \mathrm{cm}$ 로 계속 표면장력이 높아진 반면 냉장 보관 한 시료는 $25.8 \mathrm{dyne} / \mathrm{cm}$ 의 표면장력을 유지하여 Pseudomonas sp. G314가 생산하는 생물 계면활성제는 상온에서 10 일 정도

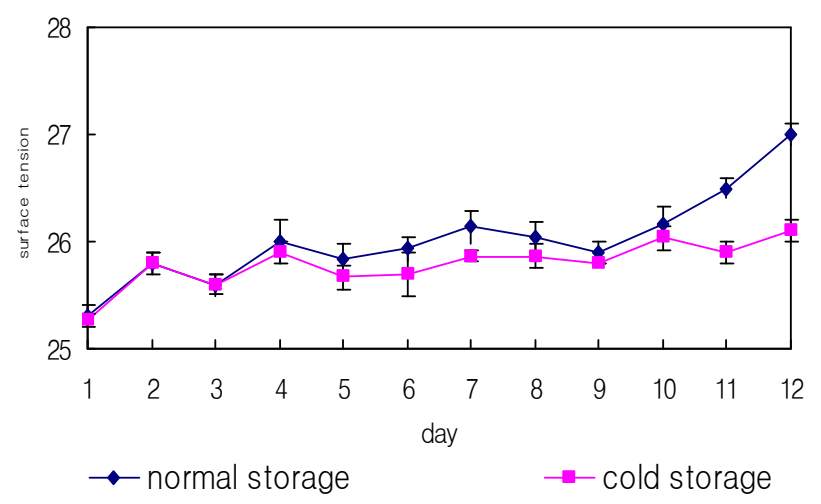

Fig. 2. Change in surface tension with the number of days stored at two different temperatures on $4^{\circ} \mathrm{C}$ and $25^{\circ} \mathrm{C}$. Data showing triplicate measurement was average. Error bars of maximum and minimum values are depicted.

Table 1. Surface tensions and critical micelle concentrations (CMCs) of various surface-active compounds in aqueous solution

\begin{tabular}{lccc}
\hline Compound & $\begin{array}{c}\text { Surface tension } \\
(\text { dyne/cm) }\end{array}$ & $\begin{array}{c}\text { CMC } \\
(\mathrm{mg} / \mathrm{l})\end{array}$ & Reference \\
\hline Ustilago maydis (cellobiolipid) & 30 & 20 & 5 \\
Corynebacterium lepus (fatty acid) & 30 & 150 & 4 \\
Pseudomonas fluorescens (carbohydrateproteinlipid) & 27 & 10 & 6 \\
Bacillus licheniformis (lipopeptide) & 27 & $12-20$ & 13 \\
Bacillus subtilis (surfactin) & 27 & 11 & 18 \\
Pseudomonas aeruginosa. (rhamnolipids) & $25-30$ & $0.1-10$ & 11 \\
Torulopsis bombicola (sophorolipids) & 33 & 82 & 9 \\
Pseudomonas sp. G314 (glycolipid) & 25 & 20 & This study \\
\hline
\end{tabular}




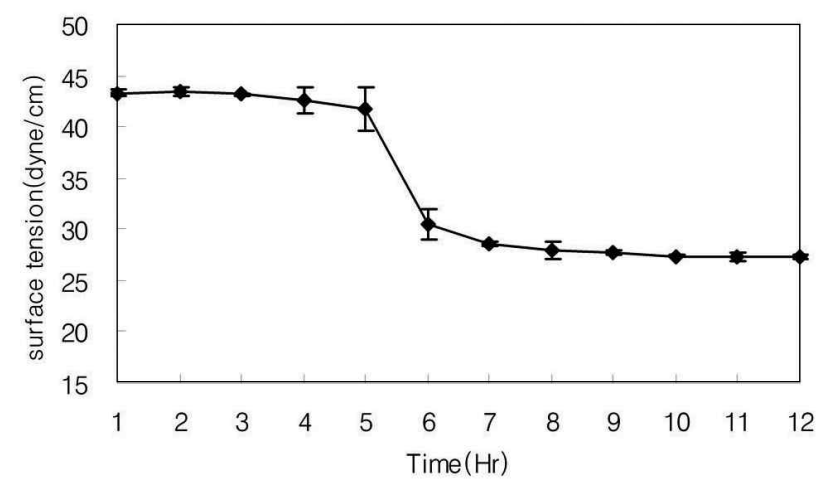

Fig. 3. Patterns of biosurfactant production from Pseudomonas sp. G11 in the fermentor. The cell was cultured in LB medium at $30^{\circ} \mathrm{C}$. Symbols show average of triplicate vial, error bars of maximum and minimum values depicted.

안정한 것으로 나타났다. 따라서 상온에서 보관하는 다른 연 구가 없어 비교하기는 어렵지만 Pseudomonas sp. G314가 생산 하는 생물 계면활성제를 상업적으로 생산했을 때 일정 기간 상온에서 보관할 수 있어 상품가치가 있을 것으로 생각된다.

\section{자동 발효기를 이용한 계면활성제 생산}

생물 계면활성제의 대량 생산가능성을 타진하기 위해 51 발효조에 21 배양액을 첨가하여 배양하며 시간에 따라 변화하 는 표면장력 값을 조사하였다(Fig. 2). 이때 발효조는 $30^{\circ} \mathrm{C}, 400$ $\mathrm{rpm}, 1: 1 \mathrm{vvm}(2 \mathrm{NV} / \mathrm{min})$ 으로 조건을 설정하여 배지 내 용존 산소가 충분하도록 하였다. 그 결과 회분배양으로 배양했을 경우 배양 3 시간 후에 $25 \mathrm{dyne} / \mathrm{cm}$ 의 표면장력 활성을 나타냈 으나[23], 51 를 발효조에서 배양했을 때는 배양 6시간 후에 $30 \mathrm{dyne} / \mathrm{cm}$ 의 표면장력 활성이 나타났고 그 후 $27 \mathrm{dyne} / \mathrm{cm}$ 까지 표면장력이 감소하여 회분배양 보다 표면장력활성이 약 간 감소함을 확인하였다. 그러나 최대감소 표면장력 값에 도 달한 후에는 회분 배양과 같이 그 값이 계속 유지되어 Pseudomonas sp. G314가 생산하는 생물 계면활성제의 대량 배양과 상업화가 가능할 것으로 생각된다.

\section{생물 계면활성제의 성분}

일반적으로 rhamnolipids 계열의 생물 계면활성제는 methanol, chloroform, ethyl acetate, ethyl ether에는 잘 녹으 나 hexane에서는 녹지 않는다고 알려져 있다 $[5,7,8,19]$. 그리고 Shim과 Park [23] 논문에서 Pseudomonas sp. G314가 생산하는 생물 계면활성제는 acetone과 methanol 등에서 잘 용해되고 benzene과 toluene에서는 소량 용해되며 hexane 등에서는 전 혀 용해되지 않아, 지금까지 알려진 glycolipid와는 달리 surfactin과 rhamnolipid와 비슷한 양상을 나타내는 새로운 종류 의 glycolipid 인 것으로 추정하였다.

Pseudomonas sp. G314가 생산하는 생물 계면활성제의 정확 한 성분을 파악하기 위해 용매로 추출한 갈색 분말상태의 생

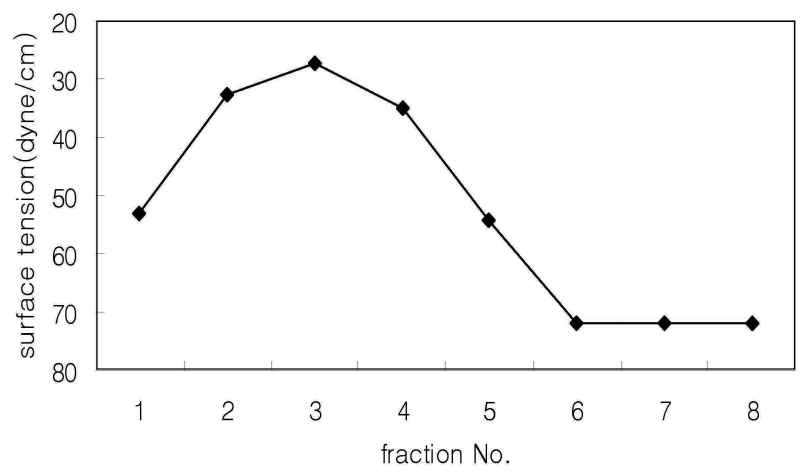

Fig. 4. Elution profile of the chromatography on silica gel G60. Column was eluted with methylene chloride:methano:acetic acid $(7: 1: 1 \%(\mathrm{v} / \mathrm{v}))$.

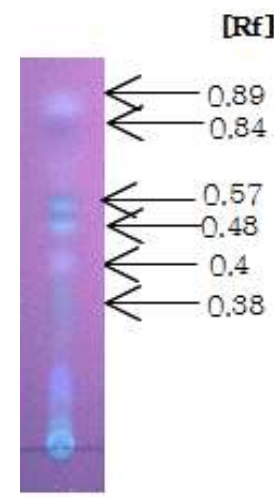

(A)

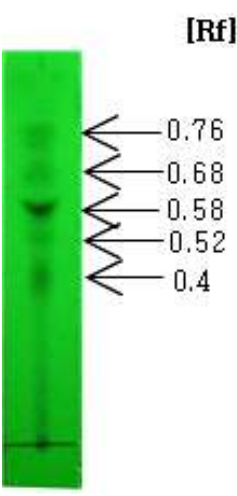

(B)
Fig. 5. TLC of crude biosurfactant. Solvent system was methylene chloride : methanol : acetic acid $(7: 1: 1 \%(\mathrm{v} / \mathrm{v}))$ and detection was done with UV lamp (254 nm/365 nm). A, $254 \mathrm{~nm} \mathrm{~B}, 365 \mathrm{~nm}$

물 계면활성제를 methylene chloride:methanol:acetic acid (7:1:1\%)로 용해시켜 동일 용매로 평형화 된 silica gel column $(2.5 \mathrm{~cm} \times 30 \mathrm{~cm})$ 에 흡착시킨 후 동일 용매로 $1 \mathrm{ml} / \mathrm{min}$ 의 속도로 용출하며 각각 $40 \mathrm{ml}$ 씩의 분획을 획득하였다(Fig. 4). 용출된 분획은 각각 감압 농축하여 $0.2 \mathrm{M}$ phosphate buffer ( $\mathrm{pH}$ 7.0)로 용해시켜 각 분획에 대한 표면장력을 측정한 결과, 분획시료 2, 3, 4번에 표면장력 활성이 있는 것으로 나타났으며, 특히 3번 분획시료의 표면장력이 $28 \mathrm{dyne} / \mathrm{cm}$ 을 나타내 분획시 료 중 가장 표면장력활성이 우수한 분획임을 확인하였다.

또 silica gel G F 254 plate (Merck, Germany)로 TLC를 전개 하여 부분 정제된 갈색분말 형태의 생물 계면활성제와 silica gel로 용출한 시료의 각 단계별 시료의 성분을 분석하였다. 이때 전개용매는 예비실험을 통해 가장 전개능력이 우수한 것으로 확인된 methylene chloride:methanol:acetic acid (7:1:1\% (v/v))의 조건으로 실험을 진행하고, $254 \mathrm{~nm}$ 와 365 $\mathrm{nm}$ 의 두 종류 파장에서 전개된 spot을 확인하고 Rf 값을 계산 하였다. 그 결과 부분 정제된 갈색의 분말은 $365 \mathrm{~nm}$ 에서는 

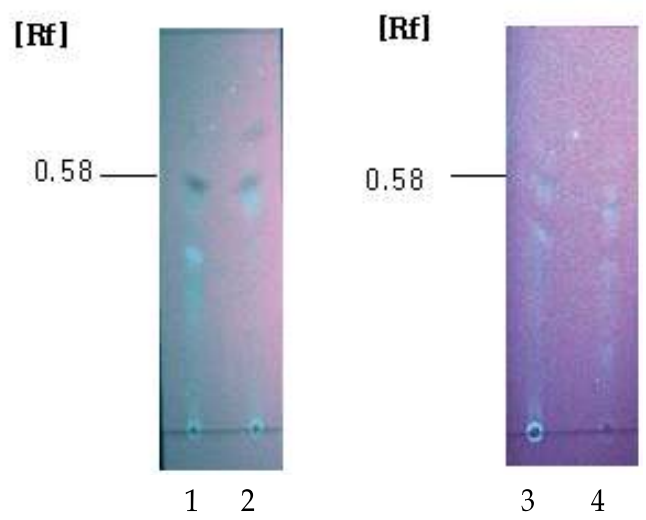

Fig. 6. Thin layer chromatography of biosurfactant purification procedure. TLC was carried out on silica gel G F254 with methylene chloride:methanol:acetic acid $(7: 1: 1 \%(\mathrm{v} / \mathrm{v}))$. Lane 1; fraction No. 2, lane 2; fraction No. 3, lane 3; fraction No. 4, and lane 4; fraction No. 5 of silica gel column chromatography (Fig. 4.).

spot이 총 6 개로 각각의 $\mathrm{Rf}$ 값이 각각 $0.4,0.48,0.57,0.84,0.89$ 로 나타났고(Fig. $5 \mathrm{~A}$ ), $254 \mathrm{~nm}$ 에서는 spot이 5개로 Rf 값은 각각 $0.4,0.52,0.58,0.68,0.76$ 로 나타났다(Fig. 5B). 그리고 silica gel column chromatography를 통해 얻은 분획시료 중 최 대감소 표면장력을 나타낸 2 번, 3 번, 4 번 분획을 각각 $\mathrm{TLC}$ plate를 이용하여 전개한 결과(Fig. 6), 표면장력 활성이 있는 3 개의 분획시료 모두에서 공통적인 spot이 확인되었고, 그 Rf 값은 0.58 로 나타났다. 그러나 최대감소 표면장력이 나타났던 3 번째 분획시료도 $\mathrm{TLC}$ 로 전개해 본 결과 단일 spot이 아닌, 3 종류의 spot을 가지고 있는 것으로 확인되어 순수하게 정제 되지 않았음을 알 수 있었다.

그리고 TLC 상에서 전개한 얻어진 부분 정제된 시료들을 탄수화물, 지질, 단백질을 검출할 수 있는 여러 종류의 coupling reagent를 이용하여 발색반응을 실시한 결과, 탄수화물 의 발색을 나타내는 Bial's reagent와 지질을 발색하는 rhodamine 6G에서 양성 반응을 나타내어 Pseudomonas sp. G314가 생산하는 생물 계면활성제는 당과 지질이 함유된 glycolipid 계의 물질임을 확인하였다(Table 2). 더구나 Bial's reagent는 탄수화물을 노란색으로 발색하는데 그 Rf 값이 0.58 로서, 정제 단계에서 표면장력이 나타난 분획에 공통적으로 나타난 spot 의 Rf 값 0.58 과 일치하여 Pseudomonas sp. G314가 생산하는 생물 계면활성제 성분의 일부가 탄수화물임을 다시 한번 확인 하였다(Fig. 7). 따라서 silica gel column chromatography를 통해 정제된 물질이 순수하게 정제된 물질이 아니지만, 주된 spot의 Rf 값과 발색시약 결과로 볼 때 Pseudomonas sp. G314 가 생산하는 생물 계면활성제는 glycolipid 종류임을 확인하 였다.

이상의 결과 Pseudomonas sp. G314가 생산하는 생물 계면활 성제는 지금까지 연구된 생물 계면활성제에 비해 표면장력
Table 2. Crude biosurfactant by colorimetric method

\begin{tabular}{llc}
\hline Substrate & Detection & Result \\
\hline Carbohydrate & $\begin{array}{l}\text { Bial's reagent } \\
\text { (orcinol ferric chloride) }\end{array}$ & + \\
Lipid & Rhodamine 6G & + \\
Amino acid & Ninhydrin & - \\
Protein & Pyridine & - \\
\hline+ , Positive; -, Negative &
\end{tabular}

[Rf]

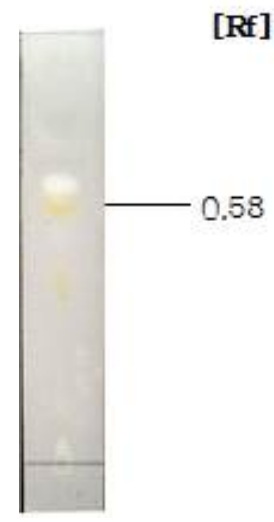

Fig. 7. TLC of biosurfactant purification procedure. Solvent system was methylene chloride:methanol:acetic acid (7:1:1\% (v/v)) and detection was done with Bial's reagent.

활성이 매우 우수하고, 온도와 $\mathrm{pH}$ 안정성 등 여러 특성이 뛰어 나 화학합성계면활성제의 대체 물질로서 사용하기에 적절하 다고 사료된다. 그러나 대량 생산 및 상품화 하기 위해서는 친수성인 당의 종류와 소수성인 지방의 결합양상, 전체 분자 량의 측정 등 세부적인 연구가 추후 진행되어야 할 것이다.

\section{감사의 글}

이 논문은 2011년도 한남대학교 학술연구 조성비 지원에 의하여 연구되었음.

\section{References}

1. Arima, K., A. Kakiunma, and G. Tamura. 1968. Surfactin a crystaline peptide lipid surfactant produced by Bacillus subtilis : Isolation, characterization and its inhibition of fibirin clot formation. Biochem Biophys. Res. Commun. 31, 488-494.

2. Banat, I. M., R. S Makkar, and S. S. Cameotra. 2000. Potential applications of microbial surfactants. Appl. Microbiol. Biotechnol. 53, 495-508.

3. Barathi, S. and N. Vasudevan. 2001. Utilization of petroleum hydrocarbons by Pseudomonas fluorescens isolated from a contaminated soil. Environ. Int. 26, 413-416.

4. Cooper, D. G., S. N. Liss, R. Longay, and J. E. Zajic. 1989. Surface activities of Mycobacterium and Pseudomonas. J. Ferment. Technol. 59, 97-101. 
5. Desai, J. D. and I. M. Banat. 1997. Microbial production of surfactants and their commercial potential. Microbiol. Mol. Biol. Rev. 61, 47-64.

6. Desai, A. J., K. M. Patel, and J. D. Desai. 1988. Emulsifier production by Pseudomonas fluorescens during the growth on hydrocarbons. Curr. Sci. 57, 500-501.

7. Falatko, D. M. and J. T. Novak. 1992. Effects of biologically produced surfactants on the mobility and biodegradation of petroleum hydrocarbons. Water Environ. Res. 64, 163-169.

8. Fiechter, A. 1992. Biosurfactants : Moving towards industrial application. Biotech Rev. 10, 208-217.

9. Gobbert, U., S. Lang, and F. Wagner. 1984. Sophorose lipid formation by resting cells of Torulopsis bombicola. Biotechnol. Lett. 6. 661-666.

10. Heinemann, C., V. Hylckama, E. T. van Johan, D. B. Janssen, H. J. Busscher, H. C. van der Mei, and G. Reid. 2000. Purification and characterization of a surface-binding protein from Lactobacillus fermentum RC-14 that inhibits adhesion of Enterococcus faecalis 1131. FEMS Microbiol. Lett. 190, 177-180.

11. Hisatsuka, K., T. Nakahara, Y. Sano, and K. Yamada. 1971. Formation of rhamnolipid by Pseudomonas aeruginosa. its function in hydrocarbon formentations. Agric. Biol. Chem 35, 686-692.

12. Inoue, S. 1998. Biosurfactant in cosmetic application. Proceedings of the World Conference on Biotechnology for the Fats and Oils industry. J. Am Oil Chem Soc. 65, 206-210.

13. Javaheri, M., G. E. Jennemar, M. J. Mclnerney, and R. M. Knapp. 1985. Anaerobic production of a biosurfactant by Bacillus licheniformis JF-2. Appl. Environ. Microbiol. Bioeng. 50, 698-700.

14. Kuiper, I., E. L. Lagendijk, R. Pickford, J. P. Derrick, G. E. Lamers, J. E. Thomas-Oates, B. J. Lugtenberg, and G. V. Bloemberg. 2004. Characterization of two Pseudomonas putida lipopeptide biosurfactants, putisolvin I and II, which inhibit biofilm formation and break down existing biofilms.
Mol. Microbiol. 51, 97-113.

15. Lang, S. 2002. Biological amphiphiles (microbial biosurfactants). Curr. Opin. Colloid Interf. Sci. 7, 12-20.

16. Laycock, M., P. D. Hildebrand, P. Thibault, J. A. Walter, and J. L. C. Wright. 1991. Viscosin, a potent peptidolipid biosurfactant and phytopathogenic mediator produced by a pectolytic strain of Pseudomonas fluorescens. J. Agr. Food Chem 39, 483-489.

17. Lee, S. C., Y. J. Jung, J. S. Yoo, Y. S. Cho, I. H. Cha, and Y. L. Choi. 2002. Characteristics of biosurfactants produced by Bacillus sp. LSC11. Korean J. Life Sci. 12, 745-751.

18. Mulligan, C. N. and B. F. Gibbs. 1993. In Kosaric, N. (ed.), pp. 329-372, Biosurfactants-production, properties, application, M. Dekker, New York.

19. Neu, T. R. 1996. Significance of bacterial surface active compounds in interaction of bacteria with interfaces. Microbiol. Rev. 60, 151-166.

20. Noudeh, G. D., M. Housaindokht, and B. S. F. Bazzaz. 2005. Isolation, characterization, and investigation of surface and hemolytic activities of a lipopeptide biosurfactants produced by Bacillus subtilis ATCC 6633. J. Microbiol. 43, 272-276.

21. Rodrigues, L., I. M. Banat, J. Teixeira, and R. Oliveira. 2006. Biosurfactants: potential applications in medicine. $J$. Antimicrob. Chemother. 57, 609-618.

22. Rosenberg, E., A. Zuckerberg, C. Rubinoritz, and D. L. Gutnick. 1979. Emulsifier of Arthrobacter RAG-1: Isolation and emulsifying properties. Appl. Environ. Microbiol. 37, 402-408.

23. Shim, S. H. and K. R. Park. 2006. Characteristics of biosurfactant producing Pseudomonas sp. G314. Korean J. Microbiol. 42, 286-293.

24. Singh, P. and S. S. Cameotra. 2004. Potential applications of microbial surfactants in biomedical sciences. Trends Biotechnol. 22, 142-146.

\section{초록 : Pseudomonas sp. G314가 생산하는 생물 계면활성제의 특성}

심소희 ${ }^{1} \cdot$ 박경량 $^{2 *}$

( ${ }^{1}$ 고려대학교 의과대학 미생물학교실, ${ }^{2}$ 한남대학교 생명공학과)

대전일원의 유류오염 지역의 토양에서 분리된, 생물 계면활성제 생성능이 우수한 Pseudomonas sp. G314균주 [23]가 생산하는 생물 계면활성제의 특성을 조사하고 그 성분을 확인하였다. Pseudomonas sp. G314가 생산하는 생물 계면활성제는 상온에서 10 일 보관 후에도 $26.2 \mathrm{dyne} / \mathrm{cm}$ 정도의 표면장력을 유지해 냉장 보관한 계면활성제 와 비슷하게 안정하였고, 51 발효조를 이용한 배양에서 회분배양의 $25 \mathrm{dyne} / \mathrm{cm}$ 보다는 약간 높은 $27 \mathrm{dyne} / \mathrm{cm}$ 정도의 계면활성제를 생산해 대량 배양 할 수 있음을 확인하였다. 또 이 계면활성제는 acetone과 methanol에 잘 용해 되고 benzene과 toluene에 약하게 용해되어 glycolipid 계열의 생물계면활성제임이 추정되었고[23], 이를 silica gel column을 통해 용출하고, $\mathrm{TLC}$ 로 전개하여 확인된 Rf 0.58 인 spot이 bial's reagent와 rhodamine $6 \mathrm{G}$ 에서 양성반응을 나타내 Pseudomonas sp. G314가 생산하는 생물 계면활성제는 탄수화물과 지질이 함유된 glycolipid 계열의 생물 계면활성제임을 확인하였다. 